\title{
Clinical and Biological Significance of ESR1 Gene Alteration and Estrogen Receptors Isoforms Expression in Breast Cancer Patients
}

\author{
Anna Nagel ${ }^{1}{ }^{1}$, Jolanta Szade ${ }^{2}$, Mariola Iliszko ${ }^{3}$, Julia Elzanowska ${ }^{1}$, \\ Marzena Welnicka-Jaskiewicz ${ }^{4}$, Jaroslaw Skokowski ${ }^{5,6,7}{ }^{\circ}$, Grzegorz Stasilojc ${ }^{1}{ }^{(0)}$, \\ Jacek Bigda ${ }^{1}\left({ }^{\infty}\right.$, Rafal Sadej $^{1}\left(\mathbb{D}\right.$, Anna Zaczek $^{1}{ }^{1}$ and Aleksandra Markiewicz ${ }^{1, *(D)}$ \\ 1 Department of Medical Biotechnology, Intercollegiate Faculty of Biotechnology, \\ University of Gdansk and Medical University of Gdansk, 80-211 Gdansk, Poland; \\ anna.nagel@biotech.ug.edu.pl (A.N.); julia.elzanowska@gmail.com (J.E.); \\ gstasilojc@gumed.edu.pl (G.S.); jjbigd@gumed.edu.pl (J.B.); rsadej@gumed.edu.pl (R.S.); \\ azaczek@gumed.edu.pl (A.Z.) \\ 2 Department of Pathology, Medical University of Gdansk, 80-210 Gdansk, Poland; jszade@gumed.edu.pl \\ 3 Department of Biology and Genetics, Medical University of Gdansk, 80-211 Gdansk, Poland; \\ milisz@gumed.edu.pl \\ 4 Department of Surgical Oncology, Medical University of Gdansk, 80-211 Gdansk, Poland; \\ mwelj@gumed.edu.pl \\ 5 Department of Oncology and Radiotherapy, Medical University of Gdansk, 80-210 Gdansk, Poland; \\ jskokowski@gumed.edu.pl \\ 6 Department of Medical Laboratory Diagnostics -Biobank, Medical University of Gdansk, Gdansk, \\ 80-210 Gdansk, Poland \\ 7 Biobanking and Biomolecular Resources Research Infrastructure (BBMRI.PL), 80-210 Gdansk, Poland \\ * Correspondence: aleksandra.markiewicz@biotech.ug.edu.pl; Tel.: +48-58-349-1438
}

Received: 6 February 2019; Accepted: 12 April 2019; Published: 16 April 2019

\begin{abstract}
The amplification of estrogen receptor alpha (ER $\alpha)$ encoded by the ESR1 gene has been described as having a prognostic role in breast cancer patients. However, increased dosage of the ESR1 gene (tested by real-time PCR) is also observed in ER-negative breast cancers, which might suggest the expression of alternative isoforms of $\mathrm{ER} \alpha$ (other than classical ER $\alpha$ of $66 \mathrm{kDa}$ ). In the current work, we have investigated the ESR1 gene dosage in 402 primary breast cancer patients as well as the expression of ER $\alpha$ isoforms-ER $\alpha 66$ and ER $\alpha 36$ - on mRNA and protein levels. The obtained results were correlated with clinicopathological data of the patients. Results showed that increased ESR1 gene dosage is not related to ESR1 gene amplification measured by fluorescent in situ hybridization (FISH), but it correlates with the decreased expression of $E R \alpha 66$ isoform ( $p=0.01$ ). Interestingly, the short ER isoform ER $\alpha 36$ was expressed in samples with increased ESR1 gene dosage, suggesting that genomic aberration might influence the expression of that particular isoform. Similarly to ESR1 increased gene dosage, high ER $\alpha 36$ expression was linked with the decreased disease-free survival of the patients $(p=0.05)$, which was independent of the status of the classical $E R \alpha 66$ level in breast tumors.
\end{abstract}

Keywords: breast cancer; estrogen receptor; ER $\alpha 36, \mathrm{ER} \alpha 66$, gene amplification; prognostic factor

\section{Introduction}

Estrogen receptor alpha $(\mathrm{ER} \alpha)$ is an important prognostic and predictive factor in breast cancer. It is a ligand-activated transcription factor and its signaling governs the growth, proliferation, and survival of cancer cells. This makes it a crucial target for endocrine therapies [1]. In breast cancer, 
nuclear ER $\alpha$ levels are routinely assessed by immunohistochemical methods particularly to determine the dependency of a tumour on estrogen-driven growth [2]; together with human epidermal growth factor receptor 2 (HER2), these are the basis of the molecular subtyping of breast cancers [3].

$E R \alpha$ is encoded by the ESR1 gene located on chromosome 6. Due to its prognostic and predictive potential, ESR1 gene alterations have been studied intensively. Gene amplification, as a mechanism of gene overexpression, may influence levels of the ER $\alpha$ protein, resulting in altered growth-stimulating signaling. Thus, changes in ESR1 copy number are a subject of ever-present debate. Reported ESR1 amplification rates in breast cancer range from $0 \%$ to $75 \%$ of patients [4-9]. Observed discrepancies have been related to different analytical techniques used for ESR1 copy number analysis. We have previously developed a qPCR-based protocol measuring gene copy number alterations in topoisomerase II $\alpha$ (TOP2A), which we showed was able to detect smaller structural changes in the TOP2A gene than large fluorescent in situ hybridization (FISH) probes [10]. We have applied a similar technique for the analysis of ESR1 genomic sequence alteration [6]. With this method, we have shown that the ESR1 copy number changes (gene dosage changes) occur also in ER-negative patients and have prognostic significance. In the current study, we aimed at exploring this seemingly paradoxical observation of absent (or low) ER protein level in the presence of increased ESR1 gene dosage. Since the routine evaluation of ER in breast cancer focuses on the classical ER isoform of the molecular mass of $66 \mathrm{kDa}$ (hence its name ER $\alpha 66$ ), aberrations in the ESR1 gene were thus far correlated with levels of classical ER isoforms but omitted other ER isoforms. In 2005, Wang et al. described a 36-kDa splicing variant of the ESR1 gene, which was called ER $\alpha 36$ [11,12]. It differs from the ER $\alpha 66$ isoform by lacking both transcriptional activation domains, but retains the DNA-binding domains $[13,14]$, although new results indicate that it might act as a transcription factor [15]. Dissimilar to ER $\alpha 66$, which is usually detected in the cell nucleus, ER $\alpha 36$ localizes mainly to the cytosol and cell membrane [11,16], although nuclear localization is also observed $[15,17,18]$. ER $\alpha 36$ expression was described in ER-positive as well as in ER-negative breast cancer cell lines [17] and breast cancers $[15,19,20]$. The study performed by Lee et al. on 31 breast cancer patients describes that ER $\alpha 36$ assessed by immunohistochemical staining (IHC) is commonly expressed in breast cancers with different ER status [21]. A retrospective study of 896 breast cancer patients reveals that ER $\alpha 66$-positive patients with a high expression of ER $\alpha 36$ are less likely to benefit from hormonal therapy [19]. In vitro studies performed using various breast cancer cells indicate that ER $\alpha 36$ rapidly activates the MAPK signalling pathway, leading to uncontrolled proliferation and anti-apoptotic events [22].

Thus, we decided to explore whether the ESR1 gene dosage measured by qPCR is related to the amplification of the whole ESR1 gene and if it correlates with the expression of classical ER $\alpha 66$ as well as the short ER isoform ER $\alpha 36$. Additionally, the clinical significance of the measured parameters was assessed in the group of operable breast cancer patients.

\section{Results}

\subsection{ESR1 Gene Dosage and Copy Number in Breast Cancers}

ESR1 gene dosage was examined by qPCR in 402 samples of primary breast cancers. Increased ESR1 gene dosage (ESR1/APP ratio $\geq 2$ ) was observed in 9.2\% (37/402) of the patients. As previously reported on a smaller group of patients [4], increased ESR1 gene dosage was linked with the poor survival of the patients (Figure 1). As the literature describes the opposite findings, when ESR1 gene status was tested by FISH, it made us wonder if increased ESR1 gene dosage measured by qPCR would also correspond to ESR1 amplification analyzed by the golden standard method for gene amplification testing: FISH. For this analysis, we selected 80 breast cancer samples that were additionally tested by FISH (successful results with both methods, qPCR and FISH, were available for 58 samples). In one case, polyploidy occurred with the average number of 3.5 CEN6 and 3.7 ESR1 copies per cells; the sample was removed from the analysis. ESR1 gene status measured by qPCR and FISH did not correlate $(r=-0.042, p=0.75$, Figure 2$)$, which suggests that both methods detect different types of 
alterations. FISH and qPCR assays detect different fragments in the ESR1 gene: the FISH probe binds a region of $395 \mathrm{kbp}$, whereas with our qPCR assay, we detected an amplicon of $60 \mathrm{bp}$. Thus, FISH might detect larger, whole gene amplification, whereas qPCR might detect small changes in the ESR1 gene that go undetected by the long FISH probe. Therefore, if ESR1 gene dosage is not related to the amplification of the whole ESR1 gene, we asked if ESR1 gene dosage might be related to the altered expression of ER, including other than the classical ER $\alpha 66$ isoform, which could be the underlying factor conferring poor prognosis to breast cancer patients.
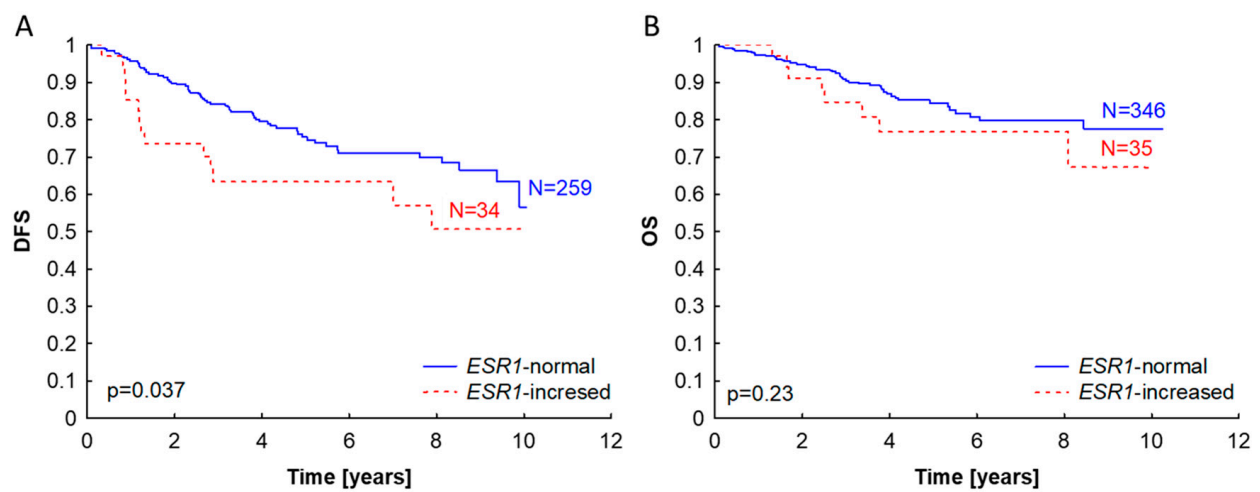

Figure 1. Kaplan-Meier survival curves according to ESR1 gene dosage status (measured by qPCR) in primary breast tumors. ESR1-normal status was described as ESR1/APP ratio <2, ESR1-increased as $E S R 1 / A P P$ ratio $\geq 2$. The probability of disease-free survival (A) and overall survival (B) are shown.

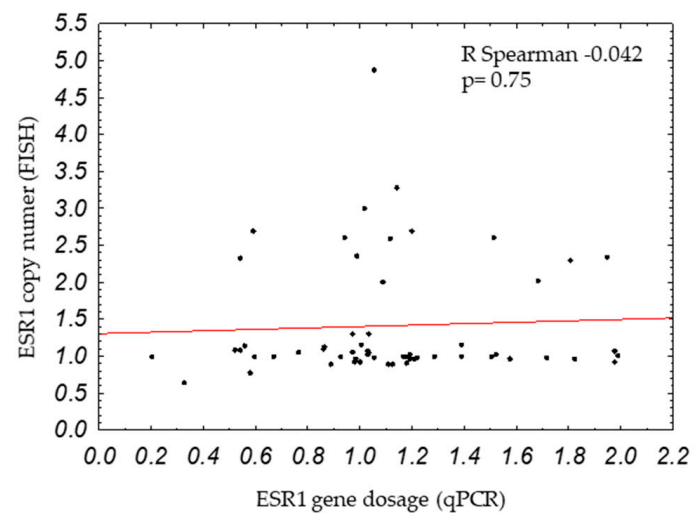

Figure 2. Correlation between ESR1 copy number (measured by fluorescent in situ hybridization, or FISH) and ESR1 gene dosage (measured by qPCR).

\subsection{Genomic ESR1 Level versus $m R N A$ and Protein Isoforms Expression}

We have analyzed the expression of ER $\alpha 36$ and ER $\alpha 66$ on mRNA level by qPCR in frozen breast cancer samples and on protein level by IHC in formalin-fixed, paraffin-embedded (FFPE) samples. The results were correlated with ESR1 gene tested by qPCR and FISH. On the mRNA level, reduced expression of the full-length ER $\alpha 66$ isoform was observed in samples with increased ESR1 gene dosage (median relative expression 10.63 in ESR1-normal gene dosage and 0 in ESR1-increased gene dosage, $p=0.01$; Figure $3 \mathrm{~A}$ ). On the contrary, increased ER $\alpha 66$ expression was found in samples with amplified ESR1 measured by FISH (median gene expression level in ESR1-amplified samples [ESR1/CEN-6 ratio <2] -64.14 and in ESR1-normal samples [ESR1/CEN-6 ratio $\geq 2]-10.28 ; p=0.00008$, Figure 3B). However, there was no correlation between ER $\alpha 36$ expression and ESR1 gene dosage (measured by qPCR; Figure 3A) or ESR1 copy number (measured by FISH; Figure 3B). The expression of ER $\alpha 36$ was observed in samples with normal and increased ESR1 gene dosage (Figure 3A), which also included ER $\alpha 66$-negative samples. However, depending on the ESR1 gene dosage, the ratio of median ER $\alpha 36$ to ER $\alpha 66$ mRNA expression level (ER $\alpha 36 / E R \alpha 66)$ was markedly different: in ESR1-increased gene 
dosage samples, the ER $\alpha 36 / E R \alpha 66$ ratio was 86, in comparison to ESR1-normal gene dosage samples, which had the ratio of 1.4. For ESR1-amplified and ESR1-normal samples by FISH, the ER $\alpha 36 / E R \alpha 66$ ratio was almost unaffected ( 0.3 versus 0.7 , respectively).
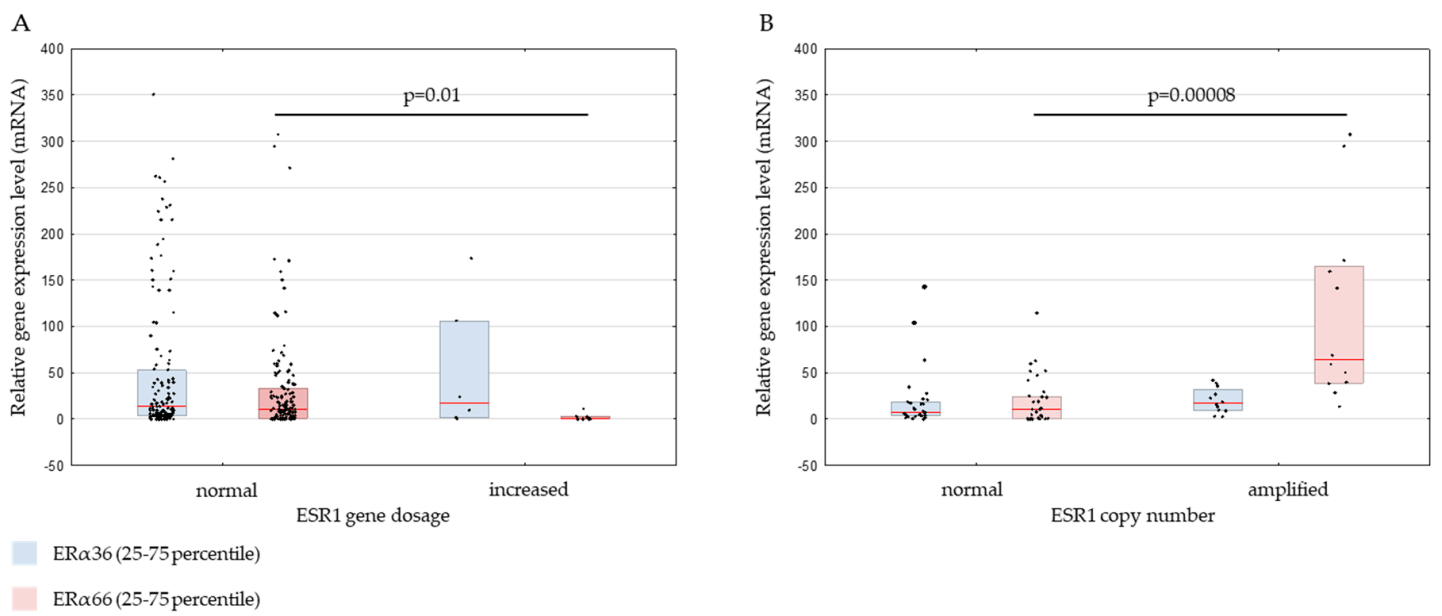

Figure 3. $E R \alpha 36$ and $E R \alpha 66$ relative gene expression levels in primary breast cancers classified according to ESR1 gene dosage status measured by qPCR (A) or ESR1 gene copy number measured by FISH (B). The vertical red line represents the median gene expression level. ${ }^{*} p<0.05,{ }^{* *} p<0.0001$. ER $\alpha$ : estrogen receptor alpha.

The ESR1 gene dosage was also inversely correlated with ER $\alpha 66$ protein level (Table 1, $p=0.001$ ) and mRNA expression ( $p=0.0086$; Table 1, Figure S3A). In samples with ESR1-increased gene dosage, $65 \%$ of samples were negative for ER $\alpha 66$ protein (according to the Allred score), whereas in samples with normal ESR1 gene dosage, only $37 \%$ of the samples were ER $\alpha 66$-negative. Therefore, in ER $\alpha 66$-negative tumors, an ESR1-increased gene dosage was found in 15\% (24/158) of the samples, in comparison to $5 \%(13 / 240)$ of the ER-positive samples. For ESR1 gene status tested by FISH, there was a good positive correlation: all the ESR1-amplified tumors were ER $\alpha 66$-positive, and none of the ER $\alpha 66$-negative tumors carried ESR1 amplification ( $p=0.0038)$. ESR1 gene copy number was also positively correlated with ER $\alpha 66$ gene expression ( $p=0.00002$; Table 1, Figure S3B). For ER $\alpha 36$ protein level (presented as the total IHC score: the sum of cytoplasmic and nuclear staining scores), no correlation was found between ESR1 gene dosage or copy number (Figure 4A,B); similarly, there was no correlation between ER $\alpha 36$ mRNA expression and the ESR1 gene by FISH and qPCR (Figure S3C,D).

Table 1. Correlation between ER $\alpha 66$ protein status, ER $\alpha 66$ gene expression, and ESR1 gene status measured by qPCR or FISH.

\begin{tabular}{|c|c|c|c|c|c|c|c|c|}
\hline \multirow[t]{2}{*}{ Header } & \multicolumn{2}{|c|}{$\begin{array}{c}\text { ESR1 Gene Dosage Status } \\
\text { (qPCR) } \\
\text { [Number of Cases }(\%)]\end{array}$} & \multirow[t]{2}{*}{ Total } & \multirow[t]{2}{*}{$p$} & \multicolumn{2}{|c|}{$\begin{array}{c}\text { ESR1 Gene Copy Number } \\
\text { (FISH) } \\
\text { [Number of Cases }(\%)]\end{array}$} & \multirow[t]{2}{*}{ Total } & \multirow[t]{2}{*}{$p$} \\
\hline & Normal & Increased & & & Normal & Amplified & & \\
\hline \multicolumn{9}{|l|}{ ER $\alpha 66$ Protein Status } \\
\hline negative & $134(37 \%)$ & $24(65 \%)$ & 158 & \multirow{3}{*}{0.001} & $21(36 \%)$ & 0 & 21 & \multirow{3}{*}{0.0038} \\
\hline positive & $227(63 \%)$ & $13(25 \%)$ & 240 & & $37(64 \%)$ & $15(100 \%)$ & 52 & \\
\hline \multirow[t]{3}{*}{ Total } & $361(100 \%)$ & $37(100 \%)$ & & & $58(100 \%)$ & $15(100 \%)$ & 73 & \\
\hline & \multicolumn{2}{|c|}{$\begin{array}{c}\text { ESR1 Gene Dosage Status } \\
\text { (qPCR) }\end{array}$} & \multirow{2}{*}{ Total } & \multirow[t]{2}{*}{$p$} & \multicolumn{2}{|c|}{$\begin{array}{l}\text { ESR1 Gene Copy Number } \\
\text { (FISH) }\end{array}$} & \multirow[t]{2}{*}{ Total } & \multirow[t]{2}{*}{$p$} \\
\hline & Normal & Increased & & & Normal & Amplified & & \\
\hline $\begin{array}{c}\text { ERa66 mRNA } \\
\text { Expression, Median } \\
(25-75 \text { Percentile })\end{array}$ & $\begin{array}{c}10.63 \\
(0.84-33.1)\end{array}$ & $\begin{array}{c}0.21 \\
(0-3.22)\end{array}$ & 145 & 0.0086 & $\begin{array}{c}10.28 \\
(0.2-24.5)\end{array}$ & $\begin{array}{c}64.14 \\
(39-165.3)\end{array}$ & 45 & 0.00002 \\
\hline
\end{tabular}


A

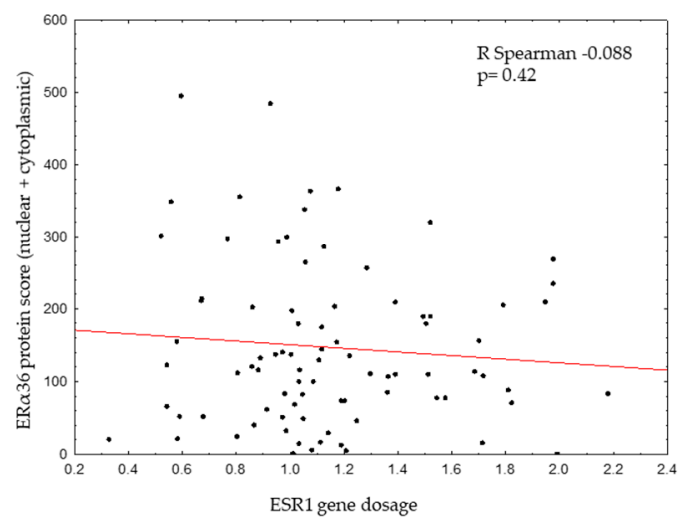

B

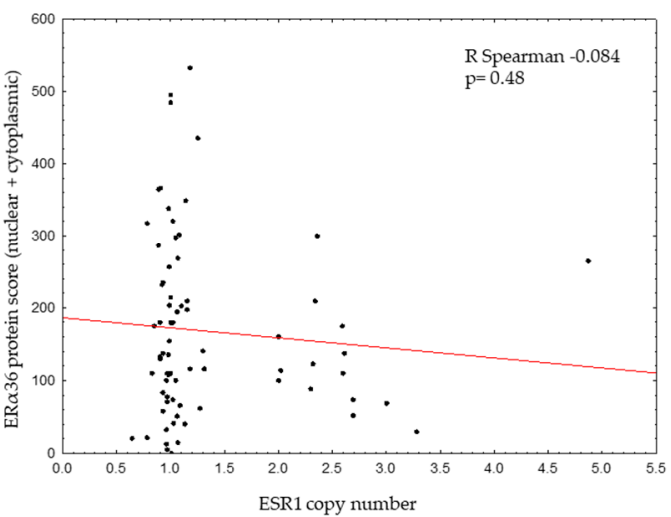

Figure 4. Correlation between ER $\alpha 36$ protein score (total nuclear and cytoplasmic score and ESR1 gene dosage (measured by qPCR) (A) or ESR1 copy number (measured by FISH) (B).

\subsection{Correlation between ER $\alpha 66$ and ER $\alpha 36$ Isoforms on $m R N A$ and Protein Level}

As expected, the level of ER $\alpha 66$ mRNA was increased in samples positive for ER $\alpha 66$ protein $(p<0.0001$, Figure 5A); in the case of ER $\alpha 36$, correlation between mRNA and protein was observed, but only for the nuclear localization ( $p=0.04$, Figure $5 B$ ). Interestingly though, ER $\alpha 36$ mRNA was expressed on a similar level in IHC ER $\alpha 66$-negative and ER $\alpha 66$-positive samples (median relative gene expression levels of 17.8 and 13.7, respectively; $p=0.99$, Figure 5C). Also on the protein level, ER $\alpha 36$ was not statistically different between ER $\alpha 66$-negative (median IHC score 82) and ER $\alpha 66$-positive samples (median IHC score 120; $p=0.19$, Mann-Whitney test, $n=126$, Figure 5D).
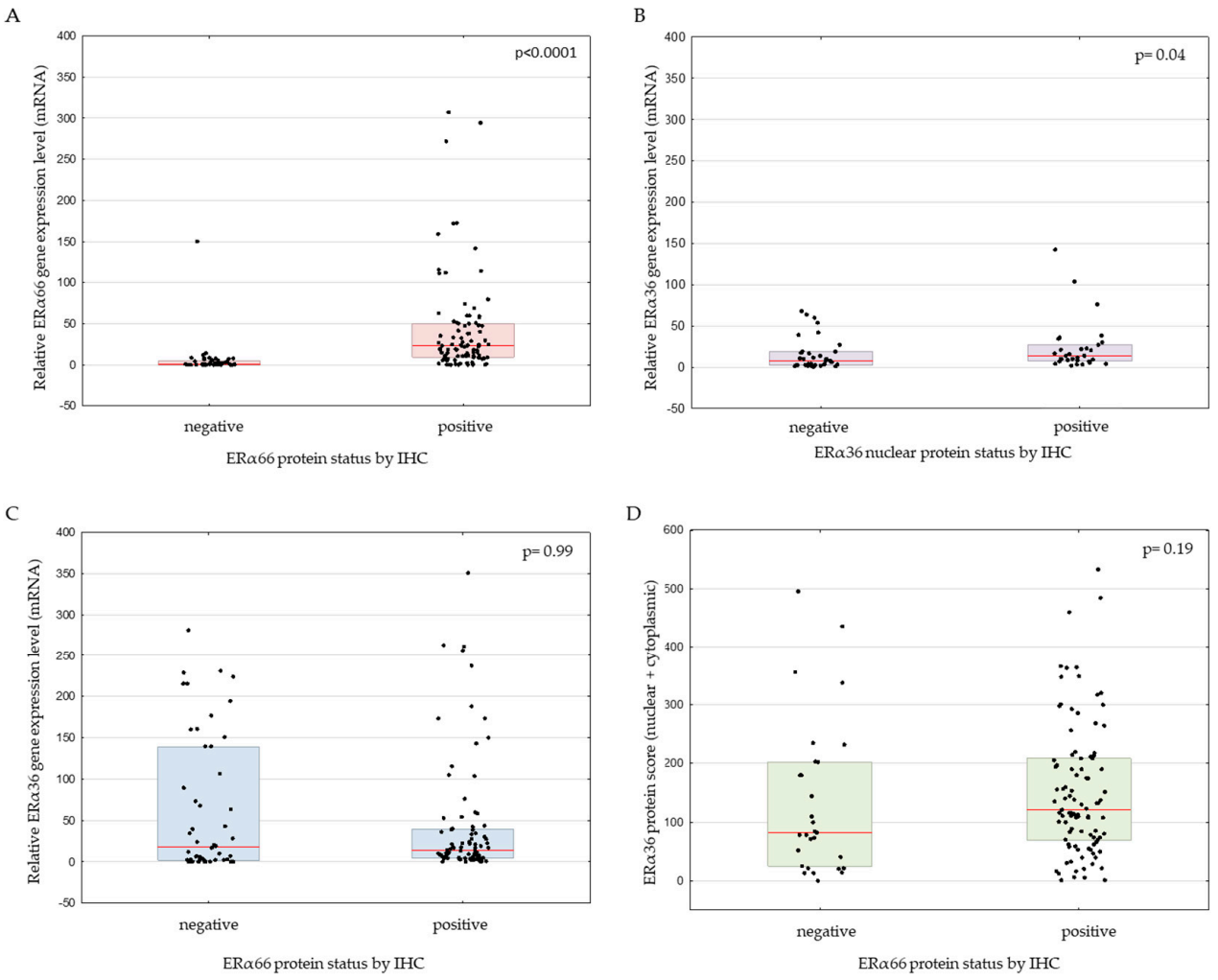

Figure 5. ER $\alpha 66$ relative expression according to ER $\alpha 66$ immunohistochemical (IHC) protein status (A), ER $\alpha 36$ relative expression according to ER $\alpha 36$ nuclear protein (B), ER $\alpha 36$ expression according to ER $\alpha 66$ protein status (C), and ER $\alpha 36$ protein immunohistochemical score according to ER $\alpha 66$ protein status (D). 
The ER $\alpha 36$ protein showed a different staining pattern than ER $\alpha 66$ : whereas ER $\alpha 66$ was mostly located in the nucleus, ER $\alpha 36$ was observed both in the nucleus and cytoplasm, and also with different immunohistochemical scores in nuclear and cytoplasmic localization (Figure 6). The presence of ER $\alpha 66$ was not associated with the localization of the ER $\alpha 36$ isoform; both nuclear and/or cytoplasmic ER $\alpha 36$ was observed in ER $\alpha 66$-negative (Figure 6A) and positive samples (Figure 6B).
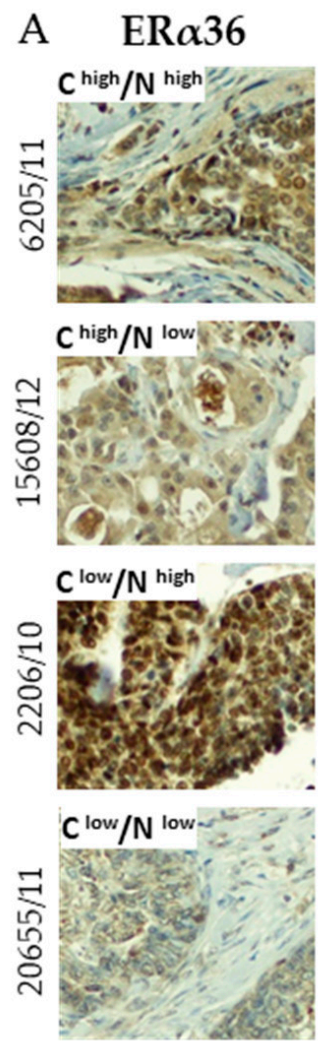

ER $\alpha 66$
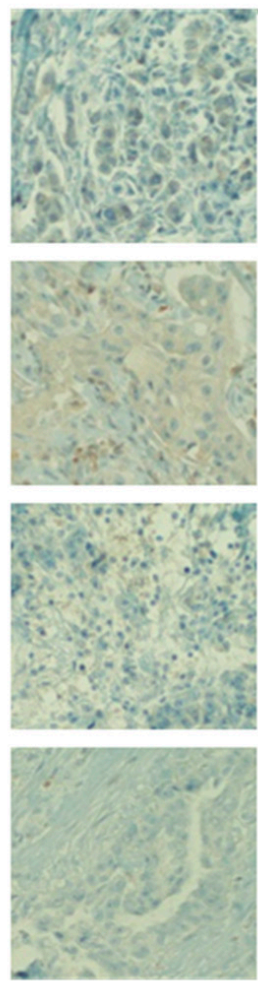
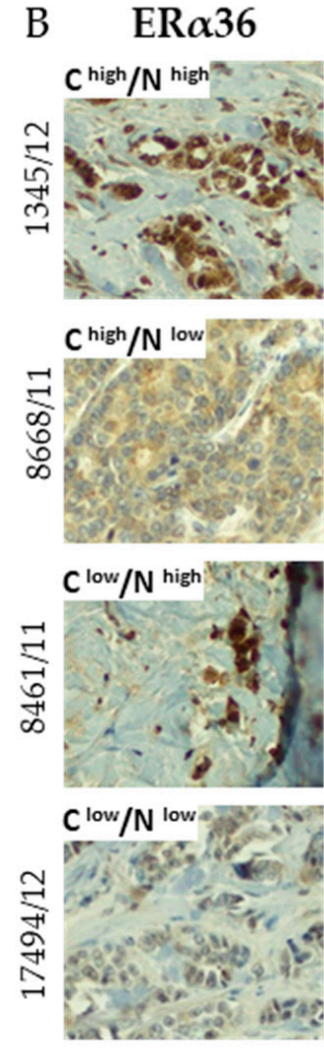

ER $\alpha 66$
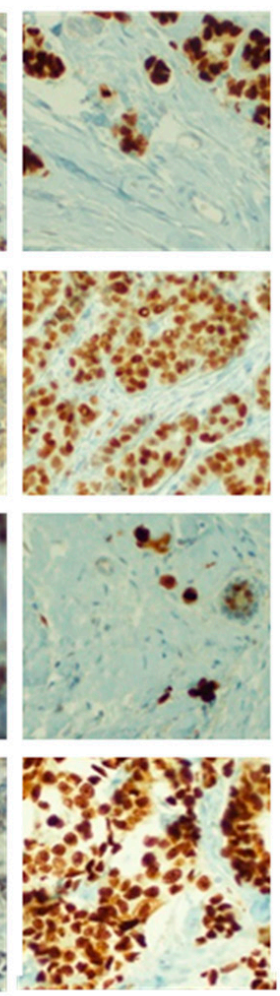

Figure 6. Exemplary photos of immunohistochemical staining of breast cancer samples with different ER $\alpha 66$ status (panel A - negative, panel B - positive according to Allred score) and ER $\alpha 36$ status. The ERa36 staining pattern has additionally been divided into positive and negative in cytoplasmic (C) and nuclear $(\mathrm{N})$ localization based on the immunohistochemical score of the samples. All photos were taken under 20× magnification.

\subsection{Clinical Significance of ER $\alpha$ Isoforms Expression}

Since we have observed ER $\alpha 36$ isoform expression in patients with ESR1 increased gene dosage and in ER $\alpha 66$-negative patients, we were interested to see how it influences the clinicopathological characteristics of the patients (Table 2). The ER $\alpha 36$ expression did not correlate with stage, grade, lymph node status, breast cancer molecular subtype, or histological tumor subtype, but its elevated expression (above median) was linked with shorter disease-free survival ( $p=0.037$; Figure 7A). Interestingly, ER $\alpha 66$ showed the exact opposite effect $(p=0.001$; Figure 7B). Survival analysis in subgroups showed that the prognostic significance of the ER $\alpha 36$ isoform was sustained in both the ER-negative and ER-positive groups (Figure 7C,D), indicating that the ER $\alpha 36$ effect is independent of the presence of the full-length ER $\alpha 66$ isoform.

On the protein level, nuclear ER $\alpha 36$ was connected with decreased overall survival ( $p=0.04)$, and cytoplasmic ER $\alpha 36$ showed a similar trend, but the result was not statistically significant $(p=0.12$; Supplementary Figure S2). Data on disease-free survival (DFS) was not available for this set of patients. 
Table 2. Correlation between ER $\alpha 36$ relative expression level (measured by $\mathrm{qPCR}$ ) and the clinicopathological characteristics of the patients. HER2: human epidermal growth factor receptor 2.

\begin{tabular}{|c|c|c|c|}
\hline Variable & $\mathbf{N}$ & $\begin{array}{l}\text { Median ER } \alpha 36 \text { Expression } \\
\text { (25-75th Percentile) }\end{array}$ & $p$ \\
\hline T stage & & & $p=0.41$ \\
\hline $\mathrm{T} 1-2$ & 127 & $13.17(3.75-42.90)$ & \\
\hline Т3-4 & 10 & $58.02(7.37-160.88)$ & \\
\hline N stage & & & $p=0.69$ \\
\hline No & 78 & $17.20(3.52-63.44)$ & \\
\hline N1 & 58 & $9.95(4.23-40.05)$ & \\
\hline Grading & & & $p=0.92$ \\
\hline 1 & 13 & $18.84(5.34-27.19)$ & \\
\hline 2 & 63 & $9.89(3.75-37.41)$ & \\
\hline 3 & 42 & $9.97(2.89-39.08)$ & \\
\hline Histological subtype & & & $p=0.21$ \\
\hline Ductal & 54 & $31.28(4.1-144.7)$ & \\
\hline Lobular & 7 & 74.39 (1.1-180.7) & \\
\hline Other & 4 & $162.13(78.1-205.5)$ & \\
\hline Molecular type & & & $p=0.84$ \\
\hline Luminal A & 17 & $16.70(4.68-150.35)$ & \\
\hline Luminal B HER2- & 13 & $11.18(3.98-24.24)$ & \\
\hline Luminal B HER2+ & 2 & $97.21(0-194.42)$ & \\
\hline Non luminal HER2+ & 6 & $83.57(0-160.88)$ & \\
\hline Triple negative & 13 & $39.56(2.88-160.1)$ & \\
\hline ER status & & & $p=0.99$ \\
\hline 0 & 50 & $17.84(1.91-139.11)$ & \\
\hline 1 & 87 & $13.71(4.41-39.08)$ & \\
\hline PR status & & & $p=0.08$ \\
\hline 0 & 52 & $10.46(1.52-53.17)$ & \\
\hline 1 & 85 & 15.77 (5.34-54.09) & \\
\hline HER2 status & & & $p=0.35$ \\
\hline 0 & 104 & $13.82(3.94-59.45)$ & \\
\hline 1 & 24 & $10.41(2.56-31.21)$ & \\
\hline
\end{tabular}
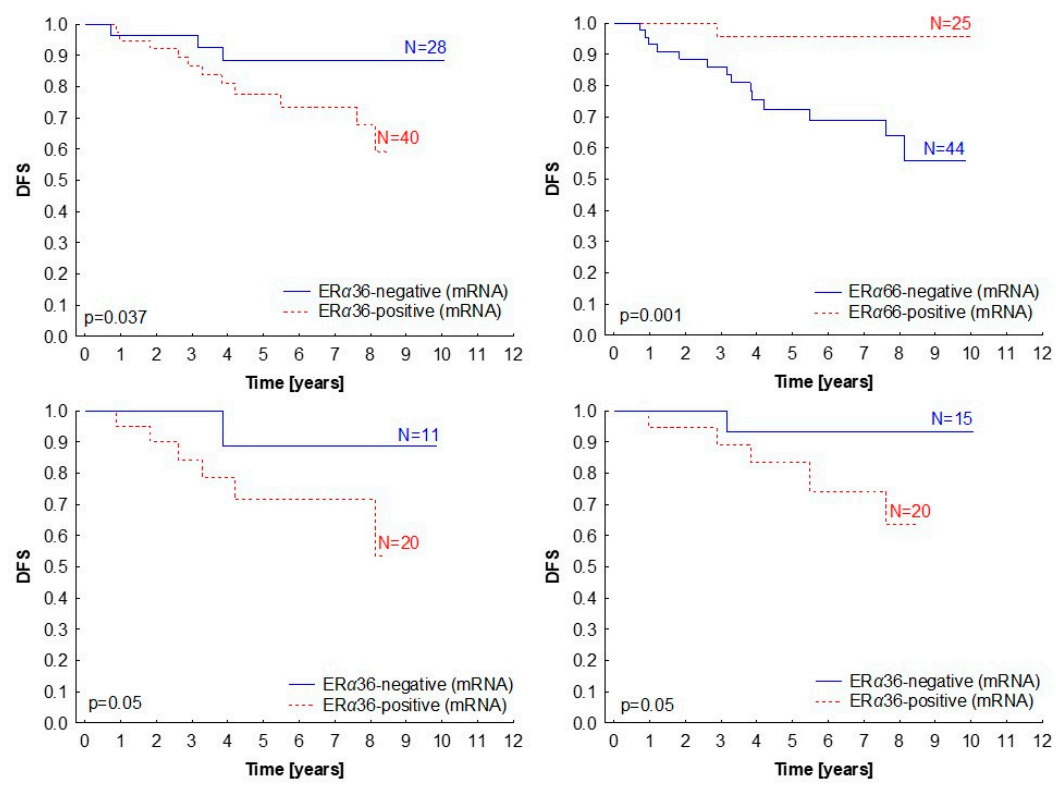

Figure 7. Kaplan-Meier survival curves presenting disease-free survival (DFS) according to ER 236 (A) and ER $\alpha 66$ (B) mRNA levels (measured by qPCR) in primary breast tumors. (C,D) Subgroup analysis for $E R \alpha 36$ expression in ER $\alpha 66$ protein-negative $(p=0.05)(\mathbf{C})$ and positive $(\mathbf{D})$ patients $(p=0.05)$. Median relative gene expression was a cut-off value for the classification of samples into negative and positive.

\subsection{The Role of ER $\alpha 36$ Isoform in Breast Cancer Cell Lines}

Similarly to clinical samples, we observed that in ER $\alpha 66$-positive cell lines, the MCF7 and BT474, ER $\alpha 36$ isoform localized independently from ER $\alpha 66$. ER $\alpha 36$ was found in the cytosol and nucleus, whereas ER $\alpha 66$ was found predominantly in cell nucleus (Figure 8). 

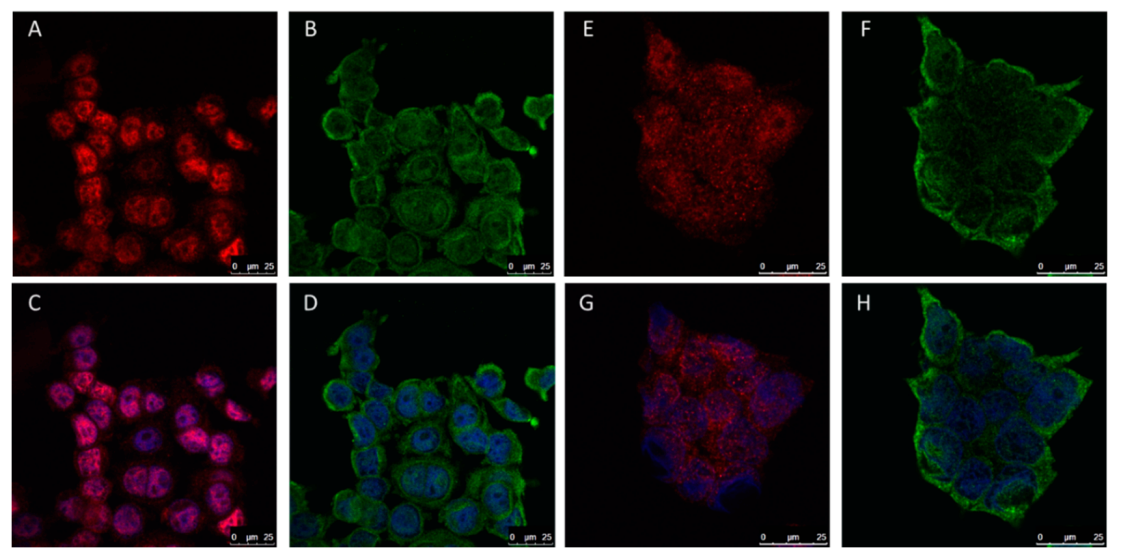

Figure 8. Immunofluorescent staining of two breast cancer cell lines: MCF7 (A-D) and BT474 (E-H). Staining for: ER $\alpha 66$ (red), ER $\alpha 36$ (green), and nucleus (blue).

Basing on our observations from the clinical samples, where the prognostic significance of ER $\alpha 36$ was observed, we asked if silencing ER $\alpha 36$ will translate to decreased migration and changes in the cell cycle of breast cancer cell lines. Three siRNAs against ER $\alpha 36$ were tested, and siRNA\#3 was chosen as it resulted in the strongest decrease in ER $\alpha 36$ protein level measured by Wester blot (Figure 9A,B). As a negative control, non-targeting siRNA was used in all the experiments. MCF7 cells with silenced ER $\alpha 36$ showed a significantly lower ability to migrate in wound-healing assay (Figure 9C,D). Silencing had no effect on cell cycle analyzed by flow cytometry (Figure 9E,F).
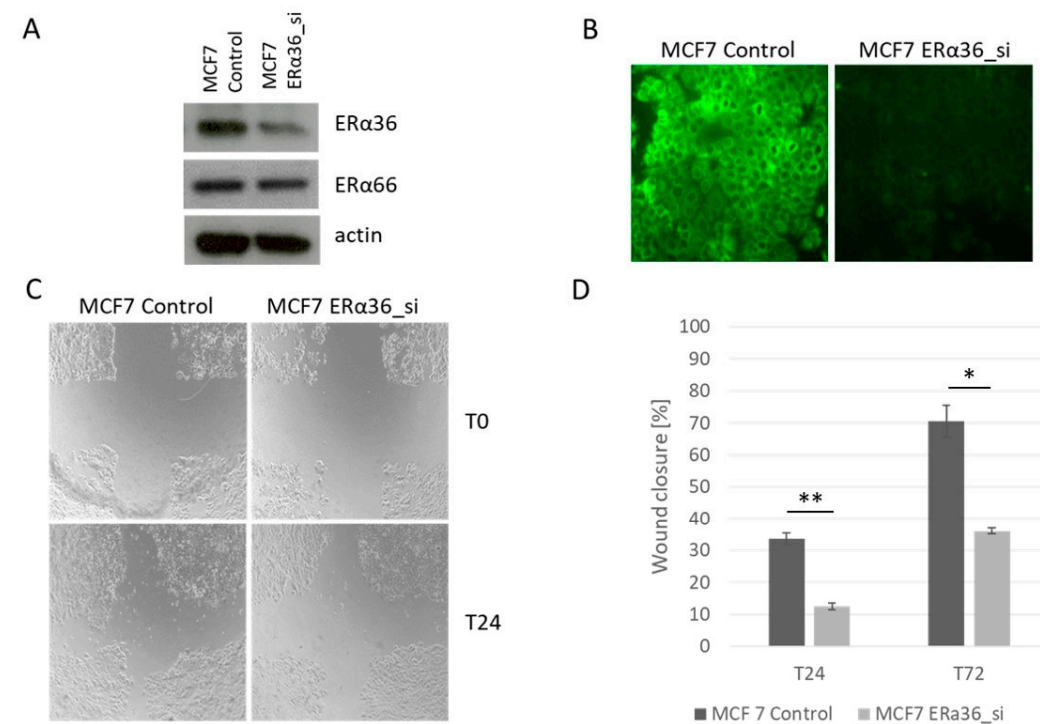

D
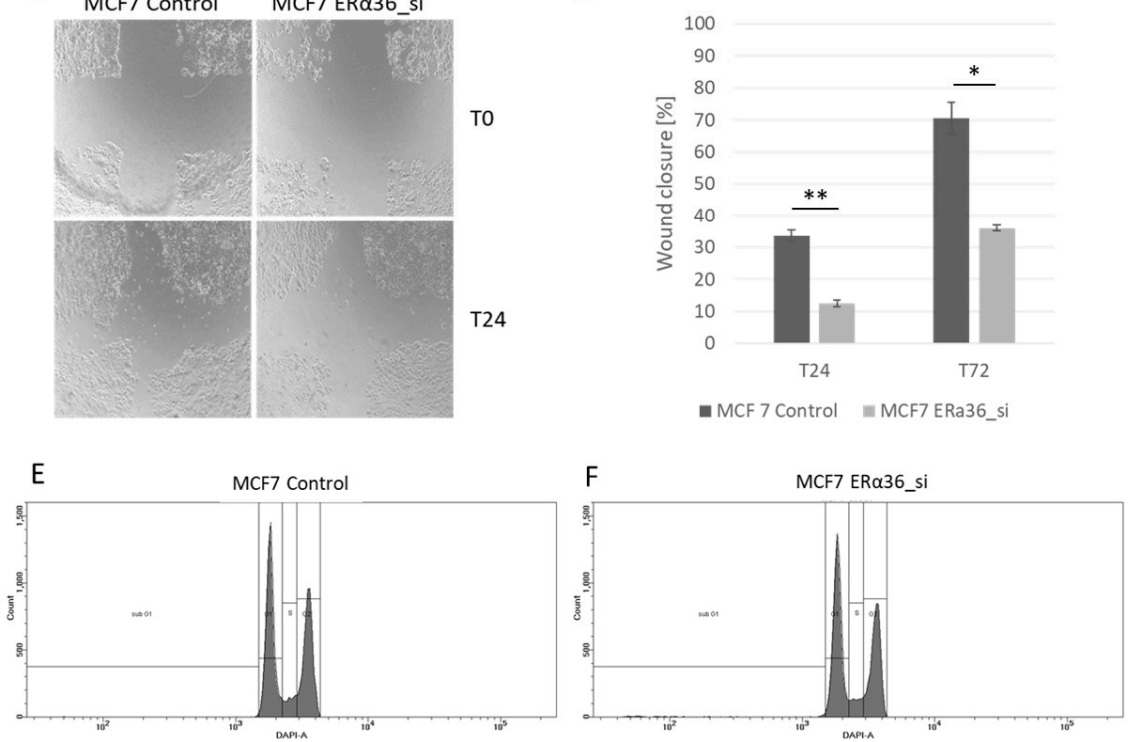

Figure 9. Silencing the ER $\alpha 36$ by siRNA confirmed by Western blotting (A) and immunofluorescence (B). Decrease in cell migration measured by wound healing assay in cells with silenced ER $\alpha 36$ $\left(\mathbf{C}, \mathbf{D},{ }^{*} p=0.005,{ }^{* *} p=0.002\right)$. Cell cycle analysis by flow cytometry in the MCF7 wild-type cell line (MCF7 Control) and with ER $\alpha 36$ silenced (MCF7 ER $\left.\alpha 36 \_s i\right)$ showed no differences in the number of cells in a given cell cycle phase $(\mathbf{E}, \mathbf{F})$. 


\section{Discussion}

As the estrogen receptor is one of the most important molecular targets in breast cancer, it is crucial to deeply understand every aspect of its functioning, as it might help to predict treatment response or disease course. The amplification of ESR1 was described in mastopathic breast tissue, which progressed to invasive cancer [23] or pre-malignant endometrial cancers [24], implying early ESR1 amplification and its role in carcinogenesis. Moreover, the amplification of ESR1 was shown to be linked with good prognosis in tamoxifen-treated breast cancer patients [4,25]. Nevertheless, large variations are reported in the frequency of ESR1 amplification in breast cancer (0-75\%, reviewed in [9]), depending on the methodology and applied cut-off values. Regarding the correlation between ESR1 amplification and the expression of ER, studies results are divided. As a general rule, in morphology-guided methods of ESR1 amplification analysis, such as FISH, correlations between gene and protein levels were more frequently observed [4,5,23,26,27]. It is still being debated if the analysis of ESR1 amplification assessed by FISH can be influenced by the FISH probe binding to the ESR1 mRNA, generating false-positive signals $[5,7,28]$. In our analysis, we have used validated FISH probes, which give similar results (ESR1 copy number) with and without RNase treatment [5], making RNase treatment a dispensable step.

We have previously reported that increased ESR1 gene dosage measured by qPCR has prognostic significance in breast cancer patients [6]. Now, we have performed additional ESR1 gene dosage analysis using the previously developed qPCR method. We observed increased ESR1 gene dosage $(E S R 1 / A P P$ ratio $\geq 2)$ in $9.4 \%$ of all patients. Interestingly, ESR1 gene dosage increase was observed more frequently in ER-negative compared to ER-positive patients (15\% versus $5 \%$ of the patients). Since gene amplification is a known mechanism for protein overexpression, one would expect the biological effect to be observed only in patients with ER-positive tumors. Therefore, we have selected a subset of sample for which ESR1 gene status was measured both with qPCR and a golden standard method: FISH. We have shown that there is no correlation between ESR1 gene dosage (measured by qPCR) and ESR1 copy number (measured by FISH), which underlines that qPCR detects different changes than FISH. We had a similar observation when analyzing changes in the topoisomerase II $\alpha$ gene (encoded by TOP2A) in breast cancers [29]. Possibly, much smaller changes are detected by qPCR than by large FISH probes spanning the whole gene sequence [10]. This would make the aberrations measured by qPCR go undetected by large FISH probes.

To our knowledge, this is the first study describing aberrations in the ESR1 gene in the context of the expression of ER isoforms. In the current work, we have tested the expression of two ER isoforms on mRNA and protein levels: classical ER $\alpha 66$ and a short variant, ER $\alpha 36$, which was recently described as playing a role in breast cancer aggressiveness [11]. Regarding the expression levels of isoforms, ESR1-increased gene dosage measured by qPCR was linked with decreased ER $\alpha 66$ expression (on the mRNA and protein level), as opposed to ESR1 amplification measured by FISH, which correlated with increased ER $\alpha 66$ protein and mRNA. In the case of the $E R \alpha 36$ isoform, no correlation was observed between ESR1 measured by qPCR or FISH. The qPCR amplicon, which is designed to detect changes in ESR1 gene dosage, is located in exon 1 of the ESR1 gene. Since small aberrations in regulatory regions might affect the expression level of a gene or its splice variants [30], it is possible that the ESR1 gene dosage alterations that we have measured by qPCR decrease the ER $\alpha 66$ level, but do not change ER $\alpha 36$ expression. Indeed, in samples with ESR1-increased gene dosage, the ER $\alpha 36 / E R \alpha 66$ ratio was over 60 times higher than that in the ESR1-normal samples. Therefore, we have investigated what is the prognostic role of ER isoforms, being especially interested in the novel ER $\alpha 36$, for which data is very limited. We observed that the two investigated isoforms have a dramatically different impact on survival. Whereas classical ER $\alpha 66$ is a marker of good prognosis, ER $\alpha 36$ was related to decreased disease-free survival, which is similar to the increased ESR1 gene dosage measured by qPCR. The prognostic effect of ER $\alpha 36$ was visible in both ER $\alpha 66$-negative and ER $\alpha 66$-positive patients. This points to ER $\alpha 66$-independent mechanism of ER $\alpha 36$ action; even in samples with high ER $\alpha 66$ expression, ER $\alpha 36$ still conferred poor prognosis. This confirms the results by Wang et al., who also reported the negative influence of ER $\alpha 36$ expression on the survival of both ER $\alpha 66$-negative and ER $\alpha 66$-positive 
breast cancer patients, especially those treated with tamoxifen [15]. The study of Shi et al. also showed the prognostic role of ER $\alpha 36$, but only in ER $\alpha 66$-positive patients treated with tamoxifen (and not in ER $\alpha 66$-negative patients) [19]. Further studies are required to uncover the dependence between ER $\alpha$ isoforms and their impact on the survival of breast cancer patients during treatment.

Other groups have reported on the expression of the ER $\alpha 36$ isoform in breast cancer cell lines $[11,17,20,31-34]$ and breast cancer patients $[15,19,20,34-36]$. Deng et al. [31,32] as well as Yin et al. [33] showed that increased ER $\alpha 36$ expression is important for the maintenance of the stem cell population in breast cancers, and Zhao indicated its role in tamoxifen resistance, which is possibly related to non-genomic signaling via the MAPK and Akt pathways [34]. On the other hand, Wang et al. proposed a mechanism in which after binding to estrogen or Tamoxifen, ER $\alpha 36$ translocates to the nucleus and acts as a transcription factor for stem cell marker ALDH1A1 [15]. The tamoxifen resistance of the MCF7 cell line was also attributed to the role of ER $\alpha 36$ in the downregulation of ER $\alpha 66$ [37]. Also, Zhang et al. described an inversed association between the expression of ER $\alpha 36$ and ER $\alpha 66$ isoforms [17]. We have not observed any correlation between the expression of the two ER isoforms, but this effect might be specific to the tumor cell type and state (such as the condition of acquired tamoxifen resistance). In the in vitro functional tests, we showed that the silencing of ER $\alpha 36$ decreased the migration of the MCF7 breast cancer cell line, which was also described by Li et al. [37]. Thus, ER $\alpha 36$ might be important for the invasive potential of cancer cells, which translates to the poor outcome of the patients.

\section{Materials and Methods}

Four hundred and eighteen primary tumours from breast cancer patients (stages I-IV) treated in the Medical University of Gdansk were investigated. Their detailed clinical characteristics are listed in Table 3. The study was granted permission from the Bioethical Committee of the Medical University of Gdansk. ESR1 gene dosage was tested using qPCR on frozen primary tumours, the data was successfully obtained for 402 samples. ESR1 gene amplification was measured using fluorescent in situ hybridization (FISH) on tissue microarrays containing 80 formalin-fixed, paraffin-embedded (FFPE) tissues samples. For ER $\alpha 36$ and ER $\alpha 66$ gene expression analysis, 149 frozen primary tumor samples were used. The median age of the patients was 58 years (27-61 years). Informed consent was collected from all the participants who were included in the study.

\subsection{RNA and DNA Isolation, Reverse Transcription, and Gene Expression Analysis}

Primary tumor samples were collected during surgery, snap frozen, and stored at $-80^{\circ} \mathrm{C}$. DNA and RNA isolation was performed usingan AllPrep DNA/RNA Kit (Qiagen, Hilden, Germany) according to the manufacturer protocol. Briefly, $30 \mathrm{mg}$ of frozen tissue was lysed in lysis buffer and ceramic beads using a MagNA Lyser (Roche, Basile, Switzerland), then added to the DNA-binding column and processed further for DNA isolation. Flow-through was used to isolate RNA with the DNase digestion step. Purified RNA (1000 ng) was reverse-transcribed with random hexamers to cDNA using a Transcriptor First Strand cDNA Synthesis Kit (Roche, Basil, Switzerland) and Mastercycler Gradient Thermal Cycler (Eppendorf, Hamburg, Germany) according to the manufacturer protocol. The expression of ER $\alpha 36$ and ER $\alpha 66$ was measured using real-time PCR with Universal PCR mastermix (Applied Biosystems, Foster City, CA, USA), giving 10 ng of cDNA per reaction. Two reference genes GAPDH and $Y W H A Z$ were chosen based on their expression stability in the tested samples. Sequences of the primers were as follows. For ERa36: forward, 5'-CCAAGAATGTTC AACCACAACCT-3'; reverse, 5' -GCACGGTTCATTAACATCTTTCTG-3' . For ER $\alpha 66$ : forward, $5^{\prime}$-AAGAAAGAAC AACATCAGCAGTAAAGTC-3'; reverse, 5' -GGGCTATGGCTTG GTTAAACAT-3'. For GAPDH: forward, 5'-ACAACTTTGGTATCGTGGAAGG-3'; reverse, 5'-GCCATCACGCCACAGTTTC-3'. For $Y W H A Z$, forward, 5'-TGTAGGAGCCCGTAGGTCATC-3'; reverse, $5^{\prime}$-GTGAAGCATTGGGGATCAAGA- $3^{\prime}$. The PCR programme used was: $95^{\circ} \mathrm{C}$ for $10 \mathrm{~min}$; 
then, 40 cycles of $95^{\circ} \mathrm{C}$ for $15 \mathrm{~s}, 60^{\circ} \mathrm{C}$ for $1 \mathrm{~min}$, and $95^{\circ} \mathrm{C}$ for $10 \mathrm{~s}$. The melting curve was performed by monitoring fluorescence in the samples, which were heated up from $65^{\circ} \mathrm{C}$ to $95^{\circ} \mathrm{C}$ in $0.5^{\circ} \mathrm{C}$ increments.

Table 3. Patient characteristics.

\begin{tabular}{|c|c|c|}
\hline \multirow{2}{*}{$\begin{array}{c}\text { Variable } \\
\text { Age }\end{array}$} & \multicolumn{2}{|c|}{ Number of Cases (\%) } \\
\hline & & \\
\hline$<50$ & 120 & (29) \\
\hline$>50$ & 298 & (71) \\
\hline \multicolumn{3}{|l|}{ T Stage } \\
\hline 1 & 140 & (33) \\
\hline 2 & 194 & $(46)$ \\
\hline 3 & 40 & (10) \\
\hline 4 & 39 & $(9)$ \\
\hline Missing data & 5 & (2) \\
\hline \multicolumn{3}{|l|}{ N Stage } \\
\hline negative & 207 & $(49)$ \\
\hline positive & 206 & (49) \\
\hline Missing data & 5 & $(2)$ \\
\hline \multicolumn{3}{|l|}{ Grade } \\
\hline 1 & 30 & (7) \\
\hline 2 & 171 & $(41)$ \\
\hline 3 & 135 & (32) \\
\hline Missing data & 82 & (20) \\
\hline \multicolumn{3}{|l|}{ Histologic Type } \\
\hline Ductal & 218 & $(52)$ \\
\hline Lobular & 54 & (13) \\
\hline Other & 26 & $(6)$ \\
\hline Missing data & 120 & (29) \\
\hline \multicolumn{3}{|l|}{ ER Status } \\
\hline negative & 164 & (39) \\
\hline positive & 250 & (59) \\
\hline Missing data & 4 & $(2)$ \\
\hline \multicolumn{3}{|l|}{ PR Status } \\
\hline negative & 175 & $(42)$ \\
\hline positive & 239 & (57) \\
\hline Missing data & 4 & $(2)$ \\
\hline \multicolumn{3}{|l|}{ HER2 Status } \\
\hline negative & 274 & (66) \\
\hline positive & 59 & (14) \\
\hline Missing data & 85 & (20) \\
\hline
\end{tabular}

\subsection{ESR1 Gene Dosage Analysis with $q P C R$}

ESR1 gene dosage in frozen primary tumors was tested according to our method described before [6]. Briefly, ESR1 gene dosage was measured in a relative manner (to APP reference gene and full blood as a calibrator) in real-time PCR (CFX96 cycler, Bio-Rad, Hercules, CA, USA) with Locked Nucleic Acid hydrolysis probes. Gene dosage equal to or higher than two was defined as ESR1 increased gene dosage.

\subsection{ESR1 Copy Number Analysis with Fluorescent in situ Hybridization}

FISH analysis was performed on tissue microarray (TMA) sections of FFPE samples from 80 breast cancer patients using a ZytoLight SPEC ESR1/CEN 6 Dual Color Probe (ZytoVision, Bremerhaven, Germany) and ZytoLight FISH-Tissue Implementation Kit (ZytoVision, Bremerhaven, Germany) according to the guidelines of the manufacturer. The evaluation of fluorescent signals was performed by the analysis of images under the fluorescent microscope. Twenty to thirty nuclei cells were evaluated per sample; the number of fluorescent signals from the ESR1 probe and centromere 6 (CEN6) probe was 
counted, averaged, and converted into a ratio of ESR1/CEN6 signal per cell. The ESR1/CEN6 ratio of $\geq 2$ was classified as ESR1 amplification, while the ESR1/CEN6 ratio between 1.3-2 was classified as gain (according to [5]). Exemplary photos of breast cancer samples analyzed for ESR1 gene amplification with FISH are shown in Figure S1.

\subsection{ERa36 Protein Level Analysis with Immunohistochemistry}

Tissue microarrays (TMA) were prepared by sampling up to five non-adjacent tissue cores of 1-mm diameter from each FFPE primary tumor. Serial sections were analyzed by manual immunohistochemical staining with commercially available rabbit antibodies against ER $\alpha 36$ specific to unique C-terminal sequence (Cell Applications Inc. San Diego, CA, USA, Cat\# CY-1109; dilution 1:800, incubation time $1 \mathrm{~h}$ ). Secondary anti-rabbit antibodies conjugated with horseradish peroxidase (HRP) were used together with the Novolink Max-Polymer Detection System (Leica Novocastra, Wetzlar, Germany) for the detection of the ER $\alpha 36$ protein. Intensity (scale 0-3) and the percentage of positively stained cells were evaluated in the nucleus and cytoplasm/membrane, giving an immunohistochemical score between 0-300. The results of the immunochistochemical staining of FFPE breast cancer samples with low and high immunohistochemical scores and the Western blotting analysis of the corresponding frozen breast cancer samples are presented in the Supplementary Figure S5.

\subsection{ERa66, PR, and HER2 Status Analysis in Breast Cancer Samples}

Hormone receptor status in breast cancer samples was assessed by IHC with mouse monoclonal antibody against ER $\alpha 66$ (clone 1D5, Dako Agilent, Santa Clara, CA, USA) and PR (clone 636, Dako Agilent, Santa Clara, CA, USA) according to the manufacturer's instructions. Antibodies were used at a dilution of 1:50; antigen retrieval was performed at neutral $\mathrm{pH}$ by water-bath heating at $90^{\circ} \mathrm{C}$ for $30 \mathrm{~min}$. Visualization was performed with the Envision Dako (Dako Agilent, Santa Clara, CA, USA) system. For ER and PR, evaluation of the immunohistochemical nuclear staining was performed based on an Allred score or the immunoreactivity of any intensity in at least $10 \%$ of the tumor cells (for older tumor samples). HER2 receptor status was analyzed by IHC: a 3+ score was considered positive, and 2+ cases were equivocal and were tested for HER2 gene amplification with FISH with the use of PathVision HER2 DNA Probe Kit (Abbott Molecular, Abbott Park, IL, USA), according to the manufacturer's instructions. The mean numbers of HER2 and centromer 17 signals were estimated for each tumor sample. A ratio of HER2/CEP-17 $\geq 2$ was considered as HER2 amplification and an HER2-positive result.

\subsection{Cell Culture}

MCF7 and BT474 cells were purchased from the American Tissue Culture Collection (ATCC, Manassas, VA, USA). Cells were passaged for a maximum of 3 to 4 months post resuscitation and routinely tested for mycoplasma contamination. MCF7 cells were cultured in DMEM supplemented with $10 \%$ fetal bovine serum (FBS). BT474 cells were maintained in RPMI- 1640 with $10 \%$ FBS and $5 \mu \mathrm{g} / \mathrm{mL}$ insulin. All the media and their supplements were from Sigma-Aldrich (Saint Louis, MO, USA) or HyClone (GE Healthcare, Chicago, IL, USA).

\subsection{Gene Knock-Down with siRNA and Western Blotting}

Cells were seeded and transfected after $24 \mathrm{~h}$ using Lipofectamine 2000 according to the producers' protocol. The siRNA used in this experiment was designed to interfere with ER $\alpha 36$ mRNA. The following sequences were chosen: sense $5^{\prime}$-AUGCCAAUAGGUACUGAA-3' and antisense 5'-UUCAGTACCUAUUGGCAU-3'. We confirmed gene silencing in the MCF7 cell line by Western blotting. Cell lysate was prepared using RIPA buffer (Sigma Aldrich, Saint Louis, MO, USA), while protein concentration was measured by a BCA assay kit (Thermo Fisher Scientific, Waltham, MA, USA). Proteins were separated using $12 \%$ polyacrylamide TGX gels (Bio-Rad, Hercules, CA, USA) and transferred onto the PVDF membrane by semi-dry transfer (Bio-Rad, Hercules, CA, USA). For 
detection, we used primary rabbit anti-ER $\alpha 36$ antibody (Cell Applications Inc. San Diego, CA, USA; dilution 1:500), mouse anti-ER $\alpha 66$ antibody (SantaCruz, Dallas, TA, USA; dilution 1:1000), and anti- $\beta$-actin antibody (Sigma Aldrich, Saint Louis, MO, USA; dilution 1:10,000). Appropriate, secondary anti-rabbit and anti-mouse HRP-conjugated antibodies were used (Sigma Aldrich, Saint Louis, MO, USA; dilution 1:100,000).

Analysis of ER $\alpha 36$ levels in frozen breast cancer samples with Western blotting was performed according to the protocol described above, apart from the homogenization step, where frozen tumor samples were cut and suspended in RIPA buffer (Sigma Aldrich, Saint Louis, MO, USA); then, tissue was minced using a sterile scalpel and centrifuged at $10,000 \times g$ for $10 \min$ in $4{ }^{\circ} \mathrm{C}$. Homogenization was followed by the measurement of protein concentration by a BCA assay kit (Thermo Fisher Scientific, Waltham, MA, USA).

\subsection{Immunofluorescent Staining}

Cells were seeded on the sterilized cover glass and after $24 \mathrm{~h}$ were fixed and permeabilized using a methanol/acetone mix for $15 \mathrm{~min}$. For blocking, 5\% BSA in PBS was used. Primary antibodies were diluted in Antibody Diluent (Dako Agilent, Santa Clara, CA, USA) and incubated with cells for $30 \mathrm{~min}$. The following antibodies were used: rabbit anti-ER $\alpha 36$ (Cell Applications Inc. San Diego, CA, US, dilution 1:1000) and mouse anti-ER $\alpha$ clone 1D5 (Dako Agilent, Santa Clara, CA, USA; dilution 1:400). As secondary antibodies, appropriately anti-rabbit IgG DyLight 488 and anti-mouse IgG DyLight 594 were used (Thermo Fisher Scientific, Waltham, MA, USA; dilution 1:2000).

\subsection{Wound-Healing Assay}

Cells were seeded into non-coated 24-well plates in full medium (DMEM with 10\% serum). Wounds were made with a sterile pipette tip after cells reached confluence, and cell debris was washed; then, incubation was performed in DMEM medium with $2 \%$ serum in order to inhibit cell proliferation. Wound closure was measured after $24 \mathrm{~h}$ using a phase-contrast microscope. Data was analyzed using the "MRI Wound Healing" ImageJ plugin, and statistical analyses ( $t$-test) were performed using MS Office Excel software.

\subsection{Cell Cycle Analysis}

Cells were seeded on the six-well plates, and after $24 \mathrm{~h}$, siRNA was added to appropriate samples. After $48 \mathrm{~h}$, cells were harvested washed with PBS and fixed with 70\% ice-cold ethanol for $30 \mathrm{~min}$. After the depletion of ethanol, the mixture of $10 \mu \mathrm{g} / \mathrm{mL}$ DAPI and $2 \mathrm{mg} / \mathrm{mL}$ RNase free from DNases in PBS was added for $15 \mathrm{~min}$. Then, cells were analyzed using a LSR II flow cytometer (BD Biosciences, Franklin Lakes, NJ, USA).

\subsection{Statistical Analysis}

All the analyses were performed using Statistica version 12 (StatSoft Dell, Round Rock, TA, USA) software. Categorical variables were compared by $\chi 2$ test. Continuous variables were compared by Spearman's rank order test. The Mann-Whitney test was used to examine the differences between continuous values in two groups. Kaplan-Meier curves for disease-free survival were compared using an F-Cox test.

\section{Conclusions}

We have shown that increased ESR1 gene dosage is found more frequently in ER $\alpha 66$-negative patients. The lack of a full-length ER isoform, ER $\alpha 66$, did not preclude the expression of a short ER $\alpha 36$ variant. The expression of both isoforms was related to patients' survival, but their effect was opposite-high ER $\alpha 66$ levels conferred good prognosis, whereas high ER $\alpha 36$ conferred poor prognosis. The obtained results underline the complexity of molecular networks in which estrogen receptor is 
involved. Together with other findings linking the expression of ER $\alpha 36$ to resistance to endocrine therapies, the role of alternative ER isoforms should be further investigated in order to uncover their biological function and clinical utility.

Supplementary Materials: The following are available online at http:/www.mdpi.com/1422-0067/20/8/1881/s1. Figure S1: ESR1 gene copy number analysis with by fluorescent in situ hybridization (FISH). Figure S2. Prognostic significance of ERa36 on protein level. Kaplan-Meier survival curves presenting overall survival (OS) according to ER $\alpha 36$ protein level in the nucleus (A) and cytoplasm (B). Division into positive/negative samples was made based on median immunohistochemical score (percentage of positively stained cells $\mathrm{x}$ intensity of the staining). Figure S3. Correlation between $E R \alpha 66(\mathrm{~A}, \mathrm{~B})$ and $E R \alpha 36(\mathrm{C}, \mathrm{D}) \mathrm{mRNA}$ expression and ESR1 gene status. ESR1 gene dosage assessed by qPCR (A, C) and ESR1 copy number assessed by FISH (B, D). Figure S4: Correlation between nuclear (A, B) as well as cytoplasmic (C, D) ER $\alpha 36$ levels and ER $\alpha 66$ assessed by immunohistochemistry. ER $\alpha 36$ levels are presented as either a percentage of positive cells (A,C) or immunohistochemical score (percentage of positive cells $(0-100 \%)$ x staining intensity (0-3); B, D). Figure S5: ER $\alpha 36$ protein levels assessed by Western blot in frozen breast cancer samples and matched FFPE samples using immunohistochemistry. ER $\alpha 36$ low - samples with low total ER $\alpha 36$ immunohistochemical score; ER $\alpha 36$ high - samples with high total ER $\alpha 36$ immunohistochemical score.

Author Contributions: Conceptualization A.N., A.M. and A.Z.; methodology A.N., J.S. (Jolanta Szade), R.S., A.Z., A.M.; formal analysis A.N., A.M.; investigation A.N., J.S. (Jolanta Szade), J.E., M.I., G.S., A.M.; resources M.W.J., J.S. (Jaroslaw Skokowski), J.B, A.Z., A.M.; writing-original draft preparation A.N., A.M.; writing-review and editing A.N., R.S., A.Z., A.M.; visualization A.N., J.S. (Jolanta Szade), M.I., G.S., A.M.; supervision A.M.; project administration A.M.; funding acquisition A.M."

Funding: This research was funded by the Ministry of Science and Higher Education program "Iuventus Plus" No. IP 2014028473 between 2015 and 2018.

Conflicts of Interest: The authors declare no conflict of interest.

\section{Abbreviations}

$\begin{array}{ll}\text { ESR1 } & \text { estrogen receptor gene } \\ \text { ER } & \text { estrogen receptor alpha } \\ \text { ER } \alpha 36 & \text { estrogen receptor alpha, 36kDa isoform } \\ \text { ER } \alpha 66 & \text { estrogen receptor alpha, 66kDa isoform } \\ \text { FISH } & \text { fluorescent in situ hybridization } \\ \text { HER2 } & \text { human epidermal growth factor receptor } \\ \text { IHC } & \text { immunohistochemistry } \\ \text { PR } & \text { progesterone receptor alpha } \\ \text { OS } & \text { overall survial } \\ \text { DFS } & \text { disease free survival }\end{array}$

\section{References}

1. Orlando, L.; Schiavone, P.; Fedele, P.; Calvani, N.; Nacci, A.; Rizzo, P.; Marino, A.; D'Amico, M.; Sponziello, F.; Mazzoni, E.; et al. Molecularly targeted endocrine therapies for breast cancer. Cancer Treat Rev. 2010, 36, 67-71. [CrossRef]

2. Hammond, M.E.; Hayes, D.F.; Dowsett, M.; Allred, D.C.; Hagerty, K.L.; Badve, S.; Fitzgibbons, P.L.; Francis, G.; Goldstein, N.S.; Hayes, M.; et al. American Society of Clinical Oncology/College of American Pathologists guideline recommendations for immunohistochemical testing of estrogen and progesterone receptors in breast cancer. Arch. Pathol. Lab. Med. 2010, 134, 907-922. [CrossRef] [PubMed]

3. Goldhirsch, A.; Winer, E.P.; Coates, A.S.; Gelber, R.D.; Piccart-Gebhart, M.; Thürlimann, B.; Senn, H.J.; Panel members. Personalizing the treatment of women with early breast cancer: Highlights of the St Gallen International Expert Consensus on the Primary Therapy of Early Breast Cancer 2013. Ann. Oncol. 2013, 24, 2206-2223. [CrossRef] [PubMed]

4. Holst, F.; Stahl, P.R.; Ruiz, C.; Hellwinkel, O.; Jehan, Z.; Wendland, M.; Lebeau, A.; Terracciano, L.; Al-Kuraya, K.; Jänicke, F.; et al. Estrogen receptor alpha (ESR1) gene amplification is frequent in breast cancer. Nat. Genet. 2007, 39, 655-660. [CrossRef]

5. Moelans, C.B.; Holst, F.; Hellwinkel, O.; Simon, R.; van Diest, P.J. ESR1 amplification in breast cancer by optimized RNase FISH: Frequent but low-level and heterogeneous. PLoS ONE 2013, 8, e84189. [CrossRef] 
6. Markiewicz, A.; Welnicka-Jaskiewicz, M.; Skokowski, J.; Jaskiewicz, J.; Szade, J.; Jassem, J.; Zaczek, A.J. Prognostic significance of ESR1 amplification and ESR1 PvuII, CYP2C19*2, UGT2B15*2 polymorphisms in breast cancer patients. PLoS ONE 2013, 8, e72219. [CrossRef]

7. Ooi, A.; Inokuchi, M.; Harada, S.; Inazawa, J.; Tajiri, R.; Kitamura, S.S.; Ikeda, H.; Kawashima, H.; Dobashi, Y. Gene amplification of ESR1 in breast cancers-fact or fiction? A fluorescence in situ hybridization and multiplex ligation-dependent probe amplification study. J. Pathol. 2012, 227, 8-16. [CrossRef] [PubMed]

8. Moelans, C.B.; Monsuur, H.N.; de Pinth, J.H.; Radersma, R.D.; de Weger, R.A.; van Diest, P.J. ESR1 amplification is rare in breast cancer and is associated with high grade and high proliferation: A multiplex ligation-dependent probe amplification study. Cell Oncol. (Dordr) 2011, 34, 489-494. [CrossRef] [PubMed]

9. Holst, F. Estrogen receptor alpha gene amplification in breast cancer: 25 years of debate. World J. Clin. Oncol. 2016, 7, 160-173. [CrossRef] [PubMed]

10. Zaczek, A.J.; Markiewicz, A.; Seroczynska, B.; Skokowski, J.; Jaskiewicz, J.; Pienkowski, T.; Olszewski, W.P.; Szade, J.; Rhone, P.; Welnicka-Jaskiewicz, M.; et al. Prognostic Significance of TOP2A Gene Dosage in HER-2-Negative Breast Cancer. Oncologist 2012, 17, 1246-1255. [CrossRef] [PubMed]

11. Wang, Z.; Zhang, X.; Shen, P.; Loggie, B.W.; Chang, Y.; Deuel, T.F. A variant of estrogen receptor-\{alpha\}, hER-\{alpha\}36: Transduction of estrogen- and antiestrogen-dependent membrane-initiated mitogenic signaling. Proc. Natl. Acad. Sci. USA 2006, 103, 9063-9068. [CrossRef] [PubMed]

12. Wang, Z.; Zhang, X.; Shen, P.; Loggie, B.W.; Chang, Y.; Deuel, T.F. Identification, cloning, and expression of human estrogen receptor-alpha36, a novel variant of human estrogen receptor-alpha66. Biochem Biophys Res. Commun. 2005, 336, 1023-1027. [CrossRef]

13. Sołtysik, K.; Czekaj, P. ER $\alpha 36-$ Another piece of the estrogen puzzle. Eur. J. Cell. Biol. 2015, 94, 611-625. [CrossRef]

14. Chaudhri, R.A.; Schwartz, N.; Elbaradie, K.; Schwartz, Z.; Boyan, B.D. Role of ER $\alpha 36$ in membrane-associated signaling by estrogen. Steroids 2014, 81, 74-80. [CrossRef]

15. Wang, Q.; Jiang, J.; Ying, G.; Xie, X.Q.; Zhang, X.; Xu, W.; Song, E.; Bu, H.; Ping, Y.F.; Yao, X.H.; et al. Tamoxifen enhances stemness and promotes metastasis of ER $\alpha 36+$ breast cancer by upregulating ALDH1A1 in cancer cells. Cell. Res. 2018, 28, 336-358. [CrossRef] [PubMed]

16. Chaudhri, R.A.; Olivares-Navarrete, R.; Cuenca, N.; Hadadi, A.; Boyan, B.D.; Schwartz, Z. Membrane estrogen signaling enhances tumorigenesis and metastatic potential of breast cancer cells via estrogen receptor- $\alpha 36$ (ER $\alpha 36)$. J. Biol. Chem. 2012, 287, 7169-7181. [CrossRef]

17. Zhang, X.T.; Kang, L.G.; Ding, L.; Vranic, S.; Gatalica, Z.; Wang, Z.Y. A positive feedback loop of ER- $\alpha 36 / E G F R$ promotes malignant growth of ER-negative breast cancer cells. Oncogene 2011, 30, 770-780. [CrossRef] [PubMed]

18. Wallacides, A.; Chesnel, A.; Ajj, H.; Chillet, M.; Flament, S.; Dumond, H. Estrogens promote proliferation of the seminoma-like TCam-2 cell line through a GPER-dependent ER $\alpha 36$ induction. Mol. Cell. Endocrinol. 2012, 350, 61-71. [CrossRef]

19. Shi, L.; Dong, B.; Li, Z.; Lu, Y.; Ouyang, T.; Li, J.; Wang, T.; Fan, Z.; Fan, T.; Lin, B.; et al. Expression of ER-\{alpha\}36, a novel variant of estrogen receptor $\{$ alpha\}, and resistance to tamoxifen treatment in breast cancer. J. Clin. Oncol. 2009, 27, 3423-3429. [CrossRef] [PubMed]

20. Zhang, J.; Li, G.; Li, Z.; Yu, X.; Zheng, Y.; Jin, K.; Wang, H.; Gong, Y.; Sun, X.; Teng, X.; et al. Estrogen-independent effects of ER- $\alpha 36$ in ER-negative breast cancer. Steroids 2012, 77, 666-673. [CrossRef]

21. Lee, L.M.; Cao, J.; Deng, H.; Chen, P.; Gatalica, Z.; Wang, Z.Y. ER-alpha36, a novel variant of ER-alpha, is expressed in ER-positive and -negative human breast carcinomas. Anticancer Res. 2008, 28, 479-483. [PubMed]

22. Schwartz, N.; Verma, A.; Bivens, C.B.; Schwartz, Z.; Boyan, B.D. Rapid steroid hormone actions via membrane receptors. Biochim. Biophys Acta. 2016, 1863, 2289-2298. [CrossRef] [PubMed]

23. Soysal, S.D.; Kilic, I.B.; Regenbrecht, C.R.; Schneider, S.; Muenst, S.; Kilic, N.; Güth, U.; Dietel, M.; Terracciano, L.M.; Kilic, E. Status of estrogen receptor 1 (ESR1) gene in mastopathy predicts subsequent development of breast cancer. Breast Cancer Res. Treat 2015, 151, 709-715. [CrossRef]

24. Lebeau, A.; Grob, T.; Holst, F.; Seyedi-Fazlollahi, N.; Moch, H.; Terracciano, L.; Turzynski, A.; Choschzick, M.; Sauter, G.; Simon, R. Oestrogen receptor gene (ESR1) amplification is frequent in endometrial carcinoma and its precursor lesions. J. Pathol. 2008, 216, 151-157. [CrossRef] 
25. Tomita, S.; Zhang, Z.; Nakano, M.; Ibusuki, M.; Kawazoe, T.; Yamamoto, Y.; Iwase, H. Estrogen receptor alpha gene ESR1 amplification may predict endocrine therapy responsiveness in breast cancer patients. Cancer Sci. 2009, 100, 1012-1017. [CrossRef]

26. Laenkholm, A.V.; Knoop, A.; Ejlertsen, B.; Rudbeck, T.; Jensen, M.B.; Muller, S.; Lykkesfeldt, A.E.; Rasmussen, B.B.; Nielsen, K.V. ESR1 gene status correlates with estrogen receptor protein levels measured by ligand binding assay and immunohistochemistry. Mol. Oncol. 2012, 6, 428-436. [CrossRef]

27. Lin, C.H.; Liu, J.M.; Lu, Y.S.; Lan, C.; Lee, W.C.; Kuo, K.T.; Wang, C.C.; Chang, D.Y.; Huang, C.S.; Cheng, A.L. Clinical significance of ESR1 gene copy number changes in breast cancer as measured by fluorescence in situ hybridisation. J. Clin. Pathol. 2013, 66, 140-145. [CrossRef]

28. Tomita, S.; Abdalla, M.O.; Fujiwara, S.; Matsumori, H.; Maehara, K.; Ohkawa, Y.; Iwase, H.; Saitoh, N.; Nakao, M. A cluster of noncoding RNAs activates the ESR1 locus during breast cancer adaptation. Nat. Commun. 2015, 6, 6966. [CrossRef]

29. Zaczek, A.; Markiewicz, A.; Jaskiewicz, J.; Pienkowski, T.; Rhone, P.; Jassem, J.; Welnicka-Jaskiewicz, M. Clinical evaluation of developed PCR-based method with hydrolysis probes for TOP2A copy number evaluation in breast cancer samples. Clinical. Biochemistry 2010, 43, 891-898. [CrossRef] [PubMed]

30. Pagani, F.; Baralle, F.E. Genomic variants in exons and introns: Identifying the splicing spoilers. Nat. Rev. Genet. 2004, 5, 389-396. [CrossRef] [PubMed]

31. Deng, H.; Yin, L.; Zhang, X.T.; Liu, L.J.; Wang, M.L.; Wang, Z.Y. ER- $\alpha$ variant ER- $\alpha 36$ mediates antiestrogen resistance in ER-positive breast cancer stem/progenitor cells. J. Steroid Biochem. Mol. Biol. 2014, 144 Pt B, 417-426. [CrossRef]

32. Deng, H.; Zhang, X.T.; Wang, M.L.; Zheng, H.Y.; Liu, L.J.; Wang, Z.Y. ER- $\alpha 36-$ mediated rapid estrogen signaling positively regulates ER-positive breast cancer stem/progenitor cells. PLoS ONE 2014, 9, e88034. [CrossRef] [PubMed]

33. Yin, L.; Pan, X.; Zhang, X.T.; Guo, Y.M.; Wang, Z.Y.; Gong, Y.; Wang, M. Downregulation of ER- $\alpha 36$ expression sensitizes HER2 overexpressing breast cancer cells to tamoxifen. Am. J. Cancer Res. 2015, 5, 530-544.

34. Zhao, Y.; Deng, C.; Lu, W.; Xiao, J.; Ma, D.; Guo, M.; Recker, R.R.; Gatalica, Z.; Wang, Z.; Xiao, G.G. let-7 microRNAs induce tamoxifen sensitivity by downregulation of estrogen receptor $\alpha$ signaling in breast cancer. Mol. Med. 2011, 17, 1233-1241. [CrossRef]

35. Li, L.; Wang, Q.; Lv, X.; Sha, L.; Qin, H.; Wang, L. Expression and localization of estrogen receptor in human breast cancer and its clinical significance. Cell Biochem. Biophys. 2015, 71, 63-68. [CrossRef] [PubMed]

36. Chamard-Jovenin, C.; Jung, A.C.; Chesnel, A.; Abecassis, J.; Flament, S.; Ledrappier, S.; Macabre, C.; Boukhobza, T.; Dumond, H. From ER $\alpha 66$ to ER $\alpha 36$ : A generic method for validating a prognosis marker of breast tumor progression. BMC Syst. Biol. 2015, 9, 28. [CrossRef]

37. Li, G.; Zhang, J.; Jin, K.; He, K.; Zheng, Y.; Xu, X.; Wang, H.; Li, Z.; Yu, X.; Teng, X.; et al. Estrogen receptor- $\alpha 36$ is involved in development of acquired tamoxifen resistance via regulating the growth status switch in breast cancer cells. Mol. Oncol. 2013, 7, 611-624. [CrossRef] [PubMed]

(C) 2019 by the authors. Licensee MDPI, Basel, Switzerland. This article is an open access article distributed under the terms and conditions of the Creative Commons Attribution (CC BY) license (http://creativecommons.org/licenses/by/4.0/). 